ROCZNIKI PEDAGOGICZNE

Tom 12(48), numer $1-2020$

DOI: http://dx.doi.org/10.18290/rped20121-7

IWONA JAZUKIEWICZ

\title{
WYCHOWANIE CZŁOWIEKA Z PERSPEKTYWY KATOLICKIEJ ETYKI WYCHOWAWCZEJ O. JACKA WORONIECKIEGO
}

Wychowanie jest procesem stwarzania warunków ku temu, by człowiek świadomie korzystał ze swojej potencjalności rozwojowej, ujawniając swoje możliwości: by uwierzył, zechciał i uznał, że powinien odpowiedzieć na noszoną godność osoby. W spotkaniu z innymi człowiek uczy się budować szczęście - najpierw własne, ale we wspólnocie z innymi, a z czasem może oddać preferencyjne miejsce szczęściu drugiego człowieka ponad własnym. Taki heroizm jest w relacji matki i dziecka, męża i żony, wychowawcy i wychowanka. I nie oznacza on wcale utraty własnego szczęścia, lecz dzielenie się nim. Człowiek jest prawdziwie szczęśliwy, gdy dzieli szczęście. Według zadziwiającej logiki, dzieląc szczęście, pomnaża je.

Każde budowanie jest solidniejsze, jeśli posiada fundamenty. Podobnie jest z budowaniem szczęścia: jego trwałość zależy od jakości źródeł. Człowiek dnia dzisiejszego, uwikłany w zdobywanie i gromadzenie światowych dóbr materialnych, psychicznych i społecznych, zatraca to, co jest stałe i trwałe, a zbiera to, co jest ulotne przez nieustanną zmienność. Zatraca fundament solidnego budowania na rzecz chwiejności i niepewności. Siedemdziesiąta rocznica pożegnania o. Jacka Woronieckiego, wielkiego wychowawcy polskiej inteligencji, jest znakomitą okazją do wzbudzenia refleksji nad tym, że człowiek dnia dzisiejszego zagubił się w rozróżnianiu tego, co warto kochać i podziwiać, a wobec czego można i nawet powinno się zdystansować. Z kolei współczesnemu wychowawcy warto uzasadnić użyteczność łączenia znawstwa nowych teorii z tymi, które są wyjmowane ze skarbca wychowania jako klasyczne. Za teorie klasyczne uznaje się te, które są

Dr hab. IwONA JAZUKIEWICZ, prof. US - Katedra Historii i Teorii Wychowania Instytutu Pedagogiki Uniwersytetu Szczecińskiego, adres do korespondencji: ul. Pawła VI nr 2, 71-459 Szczecin; e-mail: iwona.jazukiewicz@usz.edu.pl; ORCID: https://orcid.org/0000-0002-1562-6845. 
podstawowe, reprezentatywne i najcenniejsze. Za taką należy uważać katolicką etykę wychowawczą o. Jacka Woronieckiego. Wskazanie jej współczesnej użyteczności jest celem artykułu.

Traktat moralno-pedagogiczny o. Jacka Woronieckiego pt. Katolicka etyka wychowawcza jest dziełem wyjątkowym w polskiej i światowej literaturze naukowej. Na tę wyjątkowość składa się między innymi: 1) umiejętne połączenie znawstwa filozofii, w tym etyki, teologii, psychologii i pedagogiki; 2) zawarcie $w$ nim wszystkich podstaw potrzebnych do oparcia zagadnień ściśle wychowawczych na naukowym fundamencie: realistycznej filozofii Boga, metafizyki i antropologii filozoficznej; 3) nieprzemijająca wartość dzieła; jego aktualność wręcz coraz silniej potwierdza się we współczesnych okolicznościach: „wynika to z charakteru pracy, dla której fundamentem stało się niezmienne i ponadczasowe nauczanie Kościoła katolickiego" (Pańpuch, 2013, s. 41). Dzieło jest przesycone tomistycznym integralnym dążeniem do harmonijnego połączenia tego, co przyrodzone i nadprzyrodzone w człowieku we wszystkich wymiarach jego działania. Jest to koncepcja realnego spełnienia się człowieka w szczęściu w wymiarze doczesnym i wiecznym.

Autor określił główną myśl przewodnią dzieła jako: „nierozerwalną łączność, jaka istnieje w doktrynie katolickiej między etyką a pedagogiką" (Woroniecki, 2013, t. 1, s. 9). Warto zwrócić uwagę współczesnego czytelnika, że odniesienie poczynione na gruncie doktryny katolickiej jest słuszne i aktualne, lecz trudno zgodzić się ze znakomitym autorem na dokonane zawężenie. Bez względu na doktrynę, zawsze i wszędzie powinien istnieć związek pedagogiki z etyką. Jest on uzasadniony w co najmniej dwojaki sposób. Po pierwsze, historycznie: zanim powstała pedagogika jako nauka o wychowaniu, myśl o nim była rozwijana przez filozofów w ścisłej łączności z wymiarem etycznym. Po drugie, merytorycznie: proces wychowania jest jednocześnie procesem etycznego zaangażowania. Wychowawca działa dla dobra wychowanka i w poczuciu odpowiedzialności za niego. To właśnie odniesienie do drugiego człowieka, rozpatrywane w kategorii dobra i zła oraz odpowiedzialności jest fundamentalnym problemem etyki (Homplewicz, 1996, s. 178). Istnieje nierozerwalna jedność działania wychowawczego i etycznego. Zerwanie więzi pedagogiki z etyką skutkowałoby zawężeniem jej zakresu $\mathrm{z}$ nauki o integralnym wychowaniu do nauki o wykształceniu. Jest to realne zagrożenie dla współczesnej pedagogiki, jeśli teoretycy i praktycy wychowania pominą tradycyjne więzi z etyką. Od takiego pominięcia chroni poznanie i praktykowanie założeń etyki wychowawczej o. Jacka Woronieckiego. 
Wydaje się, że dominikanin przystałby na proponowane rozszerzenie związku pedagogiki z etyką poza doktryną katolicką. W swym dziele uznał przecież naukę o wychowaniu za główną część składową etyki, formułując następującą myśl:

Pedagogika jako osobna nauka, obdarzona własną jednością wewnętrzną, nie istnieje; ona jest - gdy idzie o wychowanie - jedną z głównych części składowych etyki, a jednocześnie jej sprawdzianem oraz ukoronowaniem, i nie ma nic ważniejszego dla moralisty jak mieć zawsze przed oczami tę organiczną więź, która je łączy (Woroniecki, 2013, t. 1, s. 9).

Jest to istotne przesłanie nie tylko dla moralisty, ale także dla pedagoga. Nie można tworzyć teorii o wychowaniu ani praktykować ich założeń bez uwzględnienia wymiaru moralnego: „Działanie niemoralne implikuje świadome założenie negatywnych skutków, a w związku z tym w ogóle nie może być rozważone jako postać działania wychowawczego" (Jazukiewicz, 2011, s. 159). Działania wychowawcze muszą być moralnie dobre, choć nie wyklucza to stanu, że mogą różnić się stopniem słuszności. Uznanie pedagogiki za jedną z głównych części składowych etyki przez o. Jacka Woronieckiego pociąga jednak za sobą konsekwencję odebrania jej statusu samodzielnej nauki. Współczesny pedagog na to nie przystanie. Co więcej, powinien być w ciągłej gotowości do uzasadnienia statusu pedagogiki jako odrębnej nauki rzeczowymi argumentami, ponieważ zdarza się, że przedstawiciele innych nauk podważają jej naukową autonomię. Nie należy tak czynić wobec nauki, która pełni niezmiernie ważną i konieczną funkcję integrowania treści o wychowaniu, formułowanych i weryfikowanych przez inne nauki, np. psychologię, socjologię czy również etykę.

Ojciec Jacek Woroniecki uznał moralność za najważniejszy wymiar codziennego życia. Jego celem była taka analiza zagadnień moralnych, która przysłuży się ich zrozumieniu, a nie dowodzeniu ich prawdziwości. Napisał:

Pragnąłem ułatwić tym wszystkim, którzy posiadają u nas średnie wykształcenie, obiektywne przemyślenie podstawowych zagadnień życia moralnego w świetle nauki katolickiej i pokierować tym dość złożonym procesem analitycznym, bez którego do głębszego zrozumienia tej najważniejszej dziedziny naszego życia na tym świecie dojść nie sposób" (Woroniecki, 2013, t. 1, s. 9).

Przesłanie Autora jest więc zdecydowanie bardziej etyczno-pedagogiczne niż teologiczne. Chociaż, pisząc Katolicka etykę wychowawcza, wzorował się przede wszystkim na Piśmie Świętym i teologicznym dziele św. Tomasza 
z Akwinu pt. Suma Teologiczna (Woroniecki, 2013, t. 1, s. 12-13). Jest to nieocenionym wkładem tego wybitnego specjalisty pierwszej połowy XX wieku w zakresie teologii moralnej, że zagadnienia, których był znawcą, ujął i wyłożył w sposób, który jest zrozumiały dla każdego. Ich głębia nie komplikuje zrozumienia. W związku z tym pedagog, który nie jest filozofem ani teologiem, może zrozumieć, jeśli zechce, że wychowanie zawsze jest filozoficzne, a wymiar moralny stanowi początek i koniec jego myślenia i działania zawodowego. Tym bardziej, że cechą charakterystyczną przesłania o. Jacka Woronieckiego jest praktyczność wnioskowania, o której sam napisał: „[...] tak ważnym było pokazać grę czynników moralnych w konkretnym postępowaniu człowieka oraz wysnuć z niej następnie praktyczne nakazy życia" (Woroniecki, 2013, t. 1, s. 11). Przeznaczenie treści także potwierdza wychowawczy i praktyczny wymiar opracowanej przez niego etyki. Pragnieniem autora było bowiem, by odbiorcami Katolickiej etyki wychowawczej byli: wychowawcy, rodzice, nauczyciele oraz ci, którzy się przygotowują do zawodu nauczycielskiego (Woroniecki, 2013, t. 1, s. 13).

\section{ANTROPOLOGICZNO-ETYCZNE PRZESŁANKI \\ WYZNACZAJĄCE PODSTAWOWE ZADANIA WYCHOWAWCZE}

W niniejszym opracowaniu przedstawionych zostanie kilka wybranych myśli z teorii wychowawczej Woronieckiego, ponieważ nie da się jej objąć w całości jednym artykułem. Nie ma też takiej potrzeby, gdyż współczesny czytelnik ma pozostawioną całość jako Katolicka etykę wychowawcza. Są to myśli pozostawione między innymi pedagogom jako przesłanka działania wychowawczego. Przesłania zostały poniżej wyrażone słowami o. Jacka Woronieckiego i opatrzone własną interpretacją autora tegoż artykułu.

Myśl pierwsza: „Znamiennym rysem postępowania ludzkiego [...] jest jego świadoma celowość" (Woroniecki, 2013, t. 1, s. 119).

Człowiek kieruje się w swoim postępowaniu świadomie podjętym celem. Jest on początkiem i kresem czynu. Nadaje temu czynowi kierunek i sens, czyli określoną wartość. Tylko wtedy, gdy człowiek ma poczucie wartości działania, jest w stanie maksymalnie zaangażować swój wysiłek i staranie oraz doświadczać radości jego podejmowania.

Autor Katolickiej etyki wychowawczej zwraca jednak uwagę, że nie należy poprzestawać na rozważaniu celów poszczególnych, pojedynczych czynów: „W samej bowiem rzeczy postępowanie nasze składa się nie z pojedyn- 
czych tylko czynów oderwanych od siebie, ale jakby z łańcuchów, w których cel każdego poszczególnego czynu jest ogniwem łączącym go z następnym [...]" (Woroniecki, 2013, t. 1, s. 123). Jakże adekwatne jest to przekonanie do współczesnej psychologicznej teorii optymalnego doświadczenia, autorstwa Mihalya Csikszentmihalyiego. Ten amerykański psycholog węgierskiego pochodzenia stwierdził na podstawie badań empirycznych, że optymalne doświadczanie jest czymś, co sami stwarzamy. Zamiast ulegać nieznanym siłom, czujemy, że kontrolujemy nasze działania i jesteśmy „panami swego losu". W takich momentach odczuwamy tak głębokie zadowolenie, że można określić je mianem „uniesienia”. Przechowujemy je w sobie i staje się ono miarą tego, jakie powinno być nasze życie (Csikszentmihalyi, 2005, s. 16-17). Taki stan w związku z jedną czynnością nie oznacza, że zostanie zgeneralizowany na resztę życia:

Jeżeli człowiek wyznaczy sobie osiągnięcie dość trudnego celu, z jakiego logicznie wynikają wszystkie inne cele; i jeżeli zainwestuje całą energię w rozwijanie umiejętności służących realizacji tego celu, wówczas zapanuje harmonia między uczuciami a działaniami. Dzięki temu połączą się odrębne fragmenty życia i każda czynność będzie miała sens w teraźniejszości, jak również z perspektywy przeszłości i przyszłości. W taki sposób można nadać znaczenie i sens całemu życiu (Csikszentmihalyi, 2005, s. 367-368).

Autor teorii optymalnego doświadczenia dodaje także, że: „Każdy cel może nadać znaczenie życiu człowieka - pod warunkiem, że posiada jasno wyznaczone zadania, zasady działania, zapewnia koncentrację oraz zaangażowanie" (Csikszentmihalyi, 2005, s. 368). Teoria odzwierciedla założenie, że „wydarzenia połączone są ze sobą ze względu na ich ostateczny cel; że istnieje porządek czasowy oraz relacja przyczynowo-skutkowa. Oznacza to, że wydarzenia nie są przypadkowe, lecz nakładają się we wzorzec definiowany ostatecznym celem" (Csikszentmihalyi, 2005, s. 369). Ojciec Woroniecki nazywa go celem naczelnym i przypisuje mu funkcję motywacyjną, stwierdzając:

Ten cel naczelny jest główną pobudką; bez niego nieraz nie zapragnęlibyśmy tamtych pośrednich. Które same w sobie mogą nam być nawet niemiłe, a na które się decydujemy, skoro widzimy, że bez nich upragnionego celu nie uzyskamy (Woroniecki, 2013, t. 1, s. 124).

Kwestią zasadniczą jest dookreślenie naczelnego celu. Według dominikanina jest nim pragnienie szczęścia: „zawiera ono w sobie pożądanie ukojenia wszystkich naszych potrzeb, pragnien, aspiracji we wszystkich dziedzinach, 
czy to niższych zmysłowych, czy to wyższych duchowych [...]" (Woroniecki, 2013, t. 1, s. 124). Jest to jednak ostateczny cel subiektywny. Jego subiektywność nie wyklucza powszechności: można uogólnić, że każdy człowiek dąży do tego, aby być szczęśliwym. Ojciec Woroniecki rozwinął swoje przemyślenia i wskazał ostateczny cel obiektywny. Jest nim Bóg, którego można „dosięgnąć” poznaniem i miłością (Woroniecki, 2013, t. 1, s. 129). Bóg jest źródłem szczęścia wiecznego. Etyka wychowawcza o. Jacka Woronieckiego ma przecież charakter katolicki. A jednak konsekwencje wynikające ze scharakteryzowanej przesłanki są cenną refleksją zarówno dla wierzących, jak i niewierzących wychowawców. Dotyczą one:

1. Świadomości celów bliższych i dalszych w wychowaniu.

2. Umiejętności formułowania celów i antycypacji ich konsekwencji.

3. Zdolności nadawania sensu doświadczeniom własnym i innych osób.

4. Umiejętności doboru metod i środków służących realizacji celów.

5. Współwystępowania działania i refleksji w wychowaniu.

Świadoma celowość zabezpiecza przed utratą sensu życia. Jest więc niezmiernie istotną cechą ludzkiego działania, ale też umiejętnością, którą można i należy kształtować w procesie wychowania.

Myśl druga: ,[...] w każdym [...] naszym uczynku kilka władz bierze udzial, wypełniając w nim każda właściwą sobie rolę" (Woroniecki, 2013, t. 1, s. 155).

Przedmiotem etyki są uczynki moralne. W każdym zawsze bierze udział rozum, wola i czynniki uczuciowe. Ojciec Woroniecki podkreślił i uzasadnił, że wszystkie te władze powinny być należycie przygotowane do współudziału w życiu moralnym. Kierownictwo w życiu moralnym ma przypadać rozumowi, a wykonanie - woli. Działanie obu tych władz jest jednak tak zespolone i nawzajem przenikające się, że

jedna bez drugiej obejść się nie może [...]. Wola nie może niczego chcieć, nim rozum o czymś nie pomyśli i nie podsunie jej do chcenia. Ale i rozum, aby wypełnić czynność poznawczą, wciąż potrzebuje być pobudzany przez wolę, która jest w naszej psychice tym ogólnym motorem, czyli działaczem, wprowadzającym wszystkie nasze władze w czyn (Woroniecki, 2013, t. 1, s. 159-160).

Etyka charakteryzuje władze człowieka, biorące udział w czynie moralnym, ale ich przygotowanie do tego współudziału jest zadaniem z obszaru wychowania. Jest więc istotną przesłanką dla człowieka dnia dzisiejszego, a zwłaszcza dla wychowawców, by po pierwsze - znać to, co może i powinno być w człowieku kształtowane; po drugie - harmonijnie łączyć rozwój 
każdej ze sfer, nie zaniedbując żadnej z nich, skoro tworzą one specyficzną hierarchię. Nie jest bowiem tak, że sprawne współdziałanie rozumu, woli i uczuć oznacza ich „usytuowanie na jednym poziomie”. Harmonia w tym przypadku wyraża się specyficzną hierarchią:

\begin{abstract}
pierwsze jest samorzutne i niezależne od woli poznanie otaczającego nas świata [...]. Wola reaguje wprawdzie tylko na dobro, ale prawda i jej poznanie przedstawia się jej także jako dobro człowieka, i dlatego lgnie ona do poznania prawdy i pobudza w tym celu rozum do właściwej mu czynności poznawczej. Podobnie i rozum reaguje tylko na prawdę, ale prawda ta zawiera się we wszystkim, a więc i w dobru, które może być prawdziwe, ale może też tylko takim się wydawać. Stąd rozum zajmuje się dobrem, bada jego prawdziwość i stawia przed wolą, jako przedmiot jej chcenia. Innymi słowy, działalność każdej z tych naczelnych władz człowieka może być przedmiotem działalności drugiej z nich. Mianowicie przedmiotem naszego myślenia może być chcenie; człowiek może nad nim się zastanawiać, badać je, rozumować o nim, a następnie też sądami i postanowieniami swego rozumu na nie wpływać i nim kierować. I na odwrót - przedmiotem chcenia może być i poznanie; możemy chcieć myśleć o tym lub o owym, możemy chcieć je poznać mniej lub bardziej szczegółowo; od naszej woli zależy przerwać nasz tok myśli i z jednego przedmiotu przenieść go na inny, a potem powrócić do poprzedniego. [...] Toteż i o akcie woli możemy powiedzieć, że jest rozumny, i o akcie rozumu, że jest dobrowolny (Woroniecki, 2013, t. 1, s. 160-161).
\end{abstract}

Istotne znaczenie dla uczynków moralnych mają także emocje. Charakteryzują się one między innymi właściwością generowania motywacji. Jednak nie powinny być władzą dominującą. Specyficzna hierarchia władz człowieka wyraża się bowiem w tym, że decyzje woli są zgodne z rozpoznaniem rozumu, a uczucia są podporządkowane rozumnej woli.

Wnioski dla wychowania wynikające $\mathrm{z}$ przedstawionej przesłanki są następujące:

1. Istotna jest świadomość tego, co w człowieku może podlegać zmianie. Wychowanie obejmuje rozum, wolę i uczuciowość człowieka.

2. Wychowanie rozumu to zadanie kształtowania sumienia. O ile potrzeba kształtowania sumienia jest bezdyskusyjna, o tyle samo jego rozumienie przedstawione w Katolickiej etyce wychowawczej nie jest powszechne. Na gruncie filozofii realistycznej przyjmuje się bowiem, że sumienie jest następstwem harmonijnej współpracy rozumu i woli (Gogacz, 1997). Tymczasem w doktrynie o. Woronieckiego sumienie jest działalnością praktyczną rozumu. Jego zdaniem inne stanowiska wynikają z trudności odróżniania w postępowaniu moralnym tego, co do niego wnosi rozum, od tego, co sprawia wola. Stanowisko o. Woronieckiego nie wyklucza udziału woli, skoro wcześniej przedstawiona była sprzężona praca obu władz. Wola nadaje 
sądom sumienia moc, spokój i pewność, które „bierze” ze swojej prawości w dążeniu do celu (Woroniecki, 2013, t. 1, s. 173). Niemniej rozumienie definicyjne sumienia jest następujące:

\begin{abstract}
Sumienie jest [...] następstwem świadomości naszej moralnej odpowiedzialności. Świadomością zaś nazywamy refleksję rozumu nad wszystkimi naszymi procesami psychicznymi, nie wyłączając własnej działalności tegoż rozumu. Duchowy bowiem jego charakter pozwala mu, podobnie jak woli, zajmować się własnymi swymi czynnościami, do czego władze zmysłowe nie są zdolne. Oko nie może widzieć swego widzenia ani ucho słyszeć swego słyszenia, tymczasem rozum może myśleć o swym myśleniu, podobnie jak wola może wziąć za przedmiot swego chcenia samo to chcenie i „chcieć chcieć”. Otóż to ogólne zastanawianie się rozumu nad wewnętrznymi procesami psychicznymi, nad własną swą działalnością woli, nazywamy świadomością, gdy zaś obejmuje ona i stosunek do prawa moralnego i wynikającą z niego odpowiedzialność za postępowanie i jego godziwość, nazywamy je sumieniem. [...] Możemy tedy określić sumienie jako praktyczny sąd naszego rozumu, mówiący nam, co mamy robić, a czego nie (sumienie przeduczynkowe), i orzekający już po dokonaniu uczynku o jego wartości moralnej (sumienie pouczynkowe) (Woroniecki, 2013, t. 1, s. 170-171).
\end{abstract}

Ostatecznie jednak autor stwierdza, że sumienie „nosi w sobie cechy i sądu rozumu, i aktu woli, a więc czegoś należącego jednocześnie do zakresu poznania i do zakresu chcenia i działania" (Woroniecki, 2013, t. 1, s. 172).

Sumienie nie jest nieomylne. Stąd zadanie wychowania dotyczące starannego zdobywania wiadomości, rzetelnego weryfikowania ich zgodności z prawdą, poznawanie prawa moralnego i warunków podejmowanych działań. Zadanie wychowania obejmuje też uwrażliwianie na głos sumienia, ponieważ człowiek potrafi ten głos zagłuszyć albo od niego uciec. Relatywizm prawdy i wartości sprzyja takiemu postępowaniu, co należy uznać za formę zagubienia człowieka w chaosie aksjonormatywnym, obecnym we współczesnej codzienności.

3. Wychowanie woli to zadanie kształtowania odpowiedzialnego stosunku wobec możności stanowienia o swoich czynach, czyli bycia wolnym. $Z$ przesłanki o. Jacka Woronieckiego wynika, że wybór dokonany przez wolę zawsze jest poprzedzony sądem rozumu, czyli pożądanie dobra czy też upodobanie w nim jest wtórne wobec poznania. To jest niezmiernie ważne ustalenie dla wychowania w dobie rozwoju koncepcji głoszących prymat wolności człowieka. Warto zwrócić uwagę na konsekwencje błędnego usytuowania wolności przed poznaniem, które najbardziej ogólnie można nazwać swawolą. Jest to stan, w którym człowiek postępuje dowolnie, bez konsekwencji ponoszenia odpowiedzialności za swoje czyny. Modne hasło „róbta, co chceta” 
nie jest tym samym, co „kochaj i rób, co chcesz”. Wartością etyki wychowawczej o. Woronieckiego jest między innymi to, że wyjaśnia tę istotną różnicę; kładzie on nacisk na to, że „miłość, pragnienie, radość są przede wszystkim afektami woli, a więc, że są natury duchowej, i że czynności te w sferze umysłowej są o wiele donioślejsze niż odpowiadające im uczucia w dziedzinie zmysłowej" (Woroniecki, 2013, t. 1, s. 181). I dalej podkreśla, że dla życia moralnego miłość duchowa w woli ma pierwszorzędne znaczenie, ponieważ staje się punktem wyjścia cnoty miłości. Miłość ma przeniknąć przede wszystkim wolę, a nie uczucie (Woroniecki, 2013, t. 1, s. 181). Przestrzega:

\footnotetext{
Miłość uczuciowa, gdy jej towarzyszy, może być dla niej cenną pomocą, ale może też się stać i wielką przeszkodą. Wysuwać ją na pierwszy plan to podkopywać duchowy charakter całego naszego postępowania moralnego i obniżać je do gry instynktów zwierzęcych (Woroniecki, 2013, t. 1, s. 181).
}

W zakresie współczesnego wychowania jest więc rozumienie miłości i wolności oraz kształtowanie odpowiedzialności za dokonywane wybory i podejmowane czyny. Gloryfikowanie wolności i ucieczka od odpowiedzialności są przejawem niedojrzałości moralnej.

Pierwszorzędną doniosłość dla wychowania ma również zrozumienie na podstawie etyki o. Jacka Woronieckiego odrębności upodobania od pożądania, dzięki czemu można przezwyciężyć egoizm oraz uzasadnić, że w sferze ducha nie interesowne pożądanie dobra dla naszego zadowolenia ma pierwszeństwo, lecz umiłowanie go dla niego samego. Dopiero z upodobania dobra ze względu na jego wartość (które abstrahuje od tego, czy dobro jest obecne, czy też nie), a nie ze względu na zadowolenie, jakie może dać jego osiągnięcie, powstaje pożądanie, czyli pragnienie bardziej realnego połączenia się z dobrem, do którego najpierw przylgnęło się idealnie, czyli duchowo (Woroniecki, 2013, t. 1, s. 179). Przy czym pożądanie nie jest koniecznym następstwem upodobania. Wola może zadowolić się radością z samego upodobania w dobru, jeśli jest ono nieosiągalne. Rozróżnienie dokonane przez o. Woronieckiego jest istotną przesłanką wychowania do miłości i wolności. Nie ma wolności bez miłości, bo wolność implikuje odpowiedzialność i umiłowanie prawdy rozpoznanej przez rozum. A miłowanie jest zarezerwowane dla podstawowego upodobania woli. Tymczasem zbyt często używa się nazwy miłości dla oznaczenia ,wtórnego afektu woli, jakim jest pragnienie lub pożądanie, i nawet dla afektów niższego rzędu, bo już z dziedziny uczuć zmysłowych" (Woroniecki, 2013, t. 1, s. 180). Powszechne pomylenie wy- 
nika z faktu, że te trzy podstawowe akty woli: miłość, czyli upodobanie w dobru (bez względu na to czy jest obecne, czy też nie), pragnienie, czyli pożądanie dobra (nieobecnego) i radość, czyli zadowolenie (z obecnego dobra) występują także w życiu uczuciowym, które jest zmysłowym odpowiednikiem działalności umysłowej woli (Woroniecki, 2013, t. 1, s. 180).

4. Wychowanie uczuć to zadanie ich uduchowienia tak, by mogły być ujęte w sprawności moralne, czyli cnoty. W tym zakresie, w etyce wychowawczej o. Jacka Woronieckiego znajduje się rozróżnienie, które ma nieocenione znaczenie $\mathrm{w}$ etyce i niedocenione konsekwencje $\mathrm{w}$ teorii i praktyce wychowania. Moralista rozróżnia uczucia cielesne i zmysłowe (Woroniecki, 2013, t. 1, s. 211-212). Różny jest kierunek ich rozwoju: uczucie cielesne zaczyna się od określonego procesu fizjologicznego, którego odpowiednie nasilenie sprawia odczuwanie zadowolenia lub przykrości (np. głód, chłód, choroba, odruchy organów płciowych); natomiast odwrotny jest kierunek w przypadku uczuć zmysłowych - takie uczucie zaczyna się od poznania określonego przedmiotu (zobaczenia, usłyszenia, podchwycenia węchem, pomyślenia o nim i przedstawienia sobie w wyobraźni), który w przypadku nieobojętności wzbudza upodobanie lub odrazę, będące źródłem reakcji fizjologicznej w organizmie. Odwrotny kierunek przebiegu tych dwóch typowych objawów uczuciowości można więc ująć następująco: w pierwszym przypadku od ciała do duszy, a w drugim od duszy do ciała. Dla wychowania istotne jest jeszcze drugie ustalenie autora, dotyczące wyższości pod względem bogactwa treści uczuć zmysłowych nad cielesnymi. I wreszcie przesłanka o charakterze konkluzji tego podziału: bogatsze w treść uczucia zmysłowe czerpią swe podniety przez zmysły zewnętrzne ze świata będącego poza nami i przerabiają je następnie ,w laboratorium zmysłów wewnętrznych [...]. W psychice ludzkiej bogactwo ich zwiększa ciągły związek i wzajemne oddziaływanie na siebie obu poziomów: zmysłowego i umysłowego" (Woroniecki, 2013, t. 1, s. 212). Dzięki temu właśnie można mówić o uduchowieniu uczuć i włączyć je do cnót. Samego uczucia cielesnego nie można więc uczynić przedmiotem wychowania, ponieważ nie należy ono do życia moralnego. Powstaje bowiem w głębi życia fizjologicznego, na które wola człowieka nie ma bezpośredniego wpływu. Jest natomiast możliwa kontrola przejścia uczucia cielesnego w zmysłowe, które dopiero jest moralnym czynnikiem naszego życia (Woroniecki, 2013, t. 1, s. 213).

Wychowanie uczuć ma więc zmierzać do przypisania im właściwego miejsca w moralnym postępowaniu. Kiedy człowiek podejmie określony cel, to porusza nie tylko wolę, lecz także uczucia. Choć są ważne w życiu, to jed- 
nak nie mogą nim kierować. Nie są bowiem w stanie objąć całej duchowej treści i wartości życia ani „poprowadzić” do celu, jak to czynią rozum i wola (Woroniecki, 2013, t. 1, s. 224). Brak wychowawczego starania w tym zakresie skutkuje przewagą czynników zmysłowych nad umysłowymi, czyli uprzedzającym działaniem uczuć przed rozumem i wolą. Człowiek postępuje wtedy bezcelowo lub nieodpowiedzialnie. Natomiast rezultatem wychowania powinien być stan, że osoba może zaufać swoim uczuciom. Stają się one sprzymierzeńcami władz umysłowych. Rada praktyczna moralisty dotyczy słownictwa: w dziedzinie zmysłowej powinniśmy używać określeń „lubić”, „podobać się”, natomiast w dziedzinie umysłowej - „kochać” lub „miłować” (Woroniecki, 2013, t. 1, s. 215).

Zadaniem wychowania jest tak kształtować władze biorące udział w czynach, by każda skutecznie wypełniała swoją rolę, zajmując właściwe miejsce w hierarchii: panowanie nad uczuciami pozostawia prymat woli, a obie te władze służą celom wskazanym przez rozum.

Myśl trzecia: ,[...] tylko ta etyka jest dobra i prawdziwa, która [...] uczy nie tylko o czynach dobrych i złych, ale też o stałych do nich usposobieniach, cnotach i wadach" (Woroniecki, 2013, t. 1, s. 387).

Wychowanie według założeń etyki wychowawczej o. Jacka Woronieckiego ma charakter aretologiczny. Polega na usprawnianiu człowieka do czynienia dobra dzięki cnotom moralnym. To one sprawiają, że człowiek staje się moralnie dobry dzięki aktom rozumnej i wolnej decyzji (Polak, 2013, s. 31). Jest to trudna propozycja dla współczesnej pedagogiki.

Po pierwsze, pedagodzy przejawiają pewną „nieśmiałość” wobec pojęcia cnoty. Chętniej używają określenia „sprawność moralna”, rezerwując termin „cnota” dla teologii, ewentualnie filozofii. Jest to ze stratą dla myśli o wychowaniu, ponieważ $\mathrm{w}$ wymiarze przyrodzonym cnota jest dziedzictwem wspólnym dla wszystkich, bez względu na światopogląd i wyznanie. Stanowi dziedzictwo w tym znaczeniu, że od czasów antycznej Grecji właśnie w tym słowie przekazywana jest egzystencjalna refleksja o kształcie dobrego życia w wymiarze moralnym. O ile pojęcie sprawności jest odnoszone przede wszystkim do jakości działania, o tyle cnota jest jakością osoby, choć bezpośrednio związaną z jej zachowaniami. Autor Katolickiej etyki wychowawczej wyjaśnił cnotę jako sprawność moralną, w odróżnieniu od sprawności intelektualnych i technicznych, które nie podlegają prawu moralnemu, więc też nie można ich zróżnicować na dobre i złe w zależności od stosunku wobec tego prawa (Woroniecki, 2013, t. 1, s. 399). W moralności natomiast każdej cnocie przeciwstawia się wada. Cnota jest stałą skłonnością i spraw- 
nością do czynienia moralnego dobra. Wada - jej przeciwieństwo - może uzewnętrzniać się poprzez złe moralnie postępowanie bądź zaniedbanie działania moralnie dobrego (Gałkowski, 1998, s. 85-117).

Po drugie, jest to propozycja „niemodna”. W dobie kultu nieograniczonych możliwości człowieka, propozycja „wyrzeczeń” w jego rozwoju wydaje się być nieprzystawalna do współczesnych potrzeb. Cnotę zdobywa się świadomym wysiłkiem pracy nad samym sobą, co nie może być tak popularne, jak ,niewymagające żadnych wysiłków i wyrzeczeń modne hasła nowożytne o autonomii moralnej i prymacie sumienia" (Woroniecki, 2013, t. 1, s. 431). A jednak ta nieprzystawalność paradoksalnie czyni cnotę niezwykle użyteczną. Mądrość o. Woronieckiego wskazała ją jako „środek zaradczy” na współczesne niedomagania, zwłaszcza natury wychowawczej. Taką drogą idzie psychologia pozytywna, która uczyniła cnotę swoją centralną kategorią pojęciową, dostrzegając w niej najistotniejszą przesłankę wysokiej jakości bycia.

W zakres wychowania wchodzi - zdaniem dominikanina - nie tylko usprawnianie władz, lecz także ich wiązanie w jednolitą harmonijną całość, zwaną charakterem (Woroniecki, 2013, t. 1, s. 437). Jest to jedno z podstawowych pojęć w myśli o. Woronieckiego o wychowaniu. Charakter jest to „zespół moralnych sprawności człowieka, powiązanych wewnętrznymi więzami w jedną organiczną całość" (Woroniecki, 2013, t. 1, s. 441). W praktyce oznacza to, że nie można wybrać i kształtować tylko jednej cnoty, a pozostałe zaniedbać, ponieważ są one ze sobą połączone. Jest to specyficzny związek, który polega na tym, że choć każda cnota pozostaje autonomiczna, to jednak posiadanie określonej cnoty ułatwia kształtowanie innych. Nie jest jednak możliwe automatyczne pojawianie się kolejnej cnoty na podstawie tych, które są już ukształtowane. Zaistnienie każdej cnoty jest uwarunkowane świadomą i wolną decyzją w przypadku kolejnych dobrych czynów (Jazukiewicz, 2011, s. 181). Kształtowanie charakteru nadaje postępowaniu człowieka cechę stałości, umiaru i jednolitego kierunku wobec naczelnego celu życia (Woroniecki, 2013, t. 1, s. 441). Cechy te można potraktować jako wskaźniki silnej osobowości. Specyficznym przejawem ukształtowanej w pełni cnoty jest także pogoda ducha i radość (Woroniecki, 2013, t. 1, s. 428).

Podstawę charakteru moralnego człowieka stanowią cztery cnoty kardynalne: roztropność, która doskonali rozum; męstwo, doskonalące uczucia popędliwo-bojowe; umiarkowanie - doskonali uczucia pożądliwe; sprawiedliwość - doskonali wolę. Przedmiotem wychowania i samowychowania są też cnoty teologiczne: wiara, nadzieja i miłość. Ich istnienie zależy od Boga, ale rozwój możliwy jest dopiero przy współudziale człowieka. W teorii 
o. Jacka Woronieckiego źródłem moralności jest Bóg (Woroniecki, 2013, t. 1, s. 429). Wartością teoretyczną i praktyczną etyki wychowawczej Woronieckiego jest szczegółowe omówienie wymienionych cnót. Autor przeznaczył na nie aż dwa tomy Katolickiej etyki wychowawczej.

Myśl czwarta: „Każdy ma sobie wyznaczoną miarę doskonałości” (Woroniecki, 2013, t. 3, s. 401)

Doskonałość jest pełnią życia. W etyce według założeń o. Jacka Woronieckiego ma ona charakter chrześcijański. Doskonałość chrześcijańska jest celem życia, więc dochodzenie do niej jest celem wychowania i samowychowania. Doskonałością tą może być tylko dokonanie tego, do czego istota duchowa została stworzona, czyli połączenie ze swym Stwórcą (Woroniecki, 2013, t. 3, s. 402). Jedyną drogą jej osiągnięcia jest - według założeń etyki Woronieckiego - miłość, rozpatrywana w kategorii cnoty, a nie jej poszczególnych aktów. Jest ona stałym nastawieniem, które łaska Boża utrzymuje w woli, aby kochać Boga zawsze i ponad wszystko (Woroniecki, 2013, t. 3, s. 403).

Warto zauważyć, że tak pojęta doskonałość nie jest w pełni dostępna $\mathrm{w}$ życiu doczesnym. Całkowite połączenie duszy z Bogiem możliwe jest dopiero w wieczności. Doskonałość chrześcijańska jest więc „pełnią życia nadprzyrodzonego, mającego swe źródło w łasce uświęcającej i przejawiającej się $\mathrm{w}$ działaniu cnót teologicznych oraz kierowanych przez nie wszystkich cnót moralnych" (Woroniecki, 2013, t. 3, s. 399). W doczesności więc człowiek dąży do pełni doskonałości, ale osiąga ją „tu i teraz” w sposób względny - na miarę swoich możliwości. W praktyce wychowania oznacza to stwarzanie warunków do ćwiczenia się we wszystkich cnotach.

Katolicka etyka wychowawcza o. Jacka Woronieckiego wnosi bogactwo uporządkowanej wiedzy $\mathrm{w}$ zakresie wychowania chrześcijańskiego. Warto zauważyć, że w wymiarze przyrodzonym wiedza ta może być użyteczna każdemu wychowaniu, które ma na celu dobro człowieka. Każdy przecież ideał wychowania jest opisem stanu pożądanej doskonałości, do której dąży się na miarę możliwości rozwojowych wychowanka. Doskonałość ta jest założonym, idealnym stanem ukształtowanej osobowości wychowanka, czyli pewnym dobrem. Każdy taki idealny stan osiąga się cząstkowo:

Po pierwsze, ze względu na nieuchronność popełniania błędów, wynikającą z ograniczeń właściwych ludzkiej egzystencji. Po drugie, z powodu braku możliwości wyznaczenia kresu doskonałości [...]. Z tych powodów rzeczywista doskonałość człowieka - w wymiarze przyrodzonym - zawsze pozostaje niezupełna. Cnota, 
uznawana za kres moralnego postępowania, oznacza zupełne spełnienie siebie w dostępnej człowiekowi niezupełnej doskonałości (Jazukiewicz, 2011, s. 188).

Koncepcje niechrześcijańskie mogą czerpać z katolickiej doktryny o. Jacka Woronieckiego refleksję o wtórności własnej doskonałości wobec moralnego dobra. Człowiek współczesny powinien bardziej pragnąć działania moralnie dobrego niż samej doskonałości, do której i tak dochodzi poprzez umiłowanie dobra. Ostatecznie przedstawia się to tak, jakby nie tyle człowiek posiadał cnotę, ile raczej cnota posiadła człowieka. W taki sposób Immanuel Kant obrazował zupełną doskonałość cnoty (Kant, 2005, s. 75).

Konsekwencje wynikające ze scharakteryzowanej przesłanki są następujące:

1. Cnota jest sprawnością nabytą. Stać na nią każdego na miarę indywidualnych możliwości. Dostępuje jej ten, kto podejmie pracę nad sobą i wytrwale w tym trudzie dąży do doskonałości. Cnota jest możnością wzrastania człowieka w doskonałości.

2. Potrzebę doskonałości, zgodną z rozumną naturą człowieka, można uznać za nasienie cnoty. W każdym człowieku tkwią dogodne warunki do wzrostu tego nasienia w postaci potencjalnych możliwości rozwoju (Jazukiewicz, 2011, s. 176).

3. Na indywidualną potencjalność w zakresie dochodzenia do zacności składają się: a) zdolność rozumowego poznania, umożliwiająca rozpoznanie moralnego dobra; b) wolność dążenia, umożliwiająca wybór moralnego dobra; c) uczuciowość, zapewniająca emocjonalne odniesienie się do przedmiotów poznania i dążenia; d) sprawne sumienie, umożliwiające samokontrolę zgodności dążenia z poznaniem oraz ich związku ze sferą emocjonalną. Praktykowanie każdej cnoty w drodze do doskonałości wymaga jedności działania rozumu, woli i złożonej struktury uczuciowości człowieka (Jazukiewicz, 2011, s. 177).

4. Istotne i znane, choć zbyt często łamane, są zalecenia o. Woronieckiego dotyczące osoby wychowawcy, który: a) powinien znać naukę o doskonałości, wszystkich jej składnikach i wymaganiach; b) poczuwać się do obowiązku życia jej zasadami. Tylko wtedy „przyczynia się on do wytworzenia w swym środowisku wychowawczym tej atmosfery spokoju i pogody, która młodzieży daje poczucie swobody, a zarazem bezpieczeństwa, tak koniecznych do tego, aby jej charaktery mogły rozwijać się normalnie i umacniać we wszystkim, co dobre i szlachetne" (Woroniecki, 2013, t. 3, s. 420).

Wychowanie według założeń Katolickiej etyki wychowawczej ma więc charakter aretologiczny, ale też agatologiczny. Cnota jest bowiem stałością woli w ukierunkowaniu na moralne dobro. 
Diagnoza współczesnego stylu życia wskazuje, że szczególnym zainteresowaniem cieszą się „,rzeczy” pozbawione wyższego sensu. Autorka zainteresowana filozofią i psychologią duchowego rozwoju, Halina Romanowska-Łakomy, zauważyła, że: „Młode pokolenie, idąc śladem dorosłych, [...] posiada niewiedzę w zakresie tego, co jest godne uwagi, miłości i szacunku, co warto kochać [...]" (Romanowska-Łakomy, 2003, s. 42). Banalności tej towarzyszy głupota etyczna: rodzi się w człowieku „rodzaj niewiedzy podstawowej, którą należy mieć odwagę nazwania podstawową głupotą, gdyż dotyczy niewiedzy w zakresie wartości wyższych. Pozostając w świecie pozbawionym sensu, [człowiek] staje się nieczuły na prawdziwe dobro" (Romanowska-Łakomy, 2003, s. 43). Można zastanowić się, czy jest to proces nieodwracalny. W koncepcji o. Jacka Woronieckiego wskazany jest znaczny potencjał człowieka. Z kolei współczesność wykazuje wielką podatność człowieka na zmiany. Można by te dwie przesłanki połączyć i ogłosić czas słusznej zmiany w kierunku godziwej etyki i godziwego życia. Nawet nie trzeba by jej tworzyć ani specjalnie szukać, bo taką propozycją jest etyka wychowawcza o. Jacka Woronieckiego. To wychowanie jest procesem dobrej zmiany rozwojowej w wymiarze indywidualnym i społecznym, a każdy wychowawca jest osobą odpowiedzialną za stworzenie warunków sprzyjających właściwej zmianie. Zmiana jest dobra, jeśli służy człowiekowi i społeczeństwu. Najwyraźniej w naszej pracy wychowawczej też jest jakieś niedomaganie, którego konsekwencją jest wspomniana głupota etyczna młodych (i nie tylko młodych). Najpierw wychowawca ma być „czuły” na dobro, bo tylko wtedy będzie potrafił wskazać je wychowankowi.

\section{BIBLIOGRAFIA}

Csikszentmihalyi, M. (2005). Przepływ. Taszów: Moderator.

GaŁkowski, S. (1998). Ku dobru. Aktualność filozofii wychowania Jacka Woronieckiego. Rzeszów: Wydawnictwo Wyższej Szkoły Pedagogicznej.

Gogacz, M. (1997). Osoba zadaniem pedagogiki. Warszawa: Oficyna Wydawnicza Navo.

Homplewicz, J. (1996). Etyka pedagogiczna. Rzeszów: Wydawnictwo Wyższej Szkoły Pedagogicznej.

JaZUKIEwiCZ, I. (2011). Pedeutologiczna teoria cnoty. Szczecin: Wydawnictwo Naukowe Uniwersytetu Szczecińskiego.

KANT, I. (2005). Metafizyczne podstawy nauki o cnocie. Kęty: Antyk.

PAŃPUCH, Z. (2013). Doniosłość antropologiczna pedagogiki Jacka Woronieckiego. W: J. WoroNIECKI, Katolicka etyka wychowawcza (s. 41-68). Lublin: Wydawnictwo KUL. 
PoLAK, R. (2013). Jacek Woroniecki OP - życie oraz poglądy etyczne i pedagogiczne. W: J. WoRONIECKI, Katolicka etyka wychowawcza (s. 14-40). Lublin: Wydawnictwo KUL.

RomanowsKa-ŁAкомy, H. (2003). Fenomenologia ludzkiej świętości. O sakralnych możliwościach czlowieka. Warszawa: Eneteia Wydawnictwo Szkolenia.

WoronieCKI, J. (2013). Katolicka etyka wychowawcza, t. 1-3. Lublin: Wydawnictwo KUL.

\section{WYCHOWANIE CZŁOWIEKA \\ Z PERSPEKTYWY KATOLICKIEJ ETYKI WYCHOWAWCZEJ \\ O. JACKA WORONIECKIEGO}

Celem artykułu jest wskazanie współczesnej użyteczności katolickiej etyki wychowawczej o. Jacka Woronieckiego. Człowiek współczesny, uwikłany w zdobywanie i gromadzenie światowych dóbr materialnych, psychicznych i społecznych, zatraca to, co jest stałe i trwałe, a zbiera to, co jest ulotne przez nieustanną zmienność. Zatraca fundament solidnego budowania na rzecz chwiejności i niepewności. Siedemdziesiąta rocznica pożegnania o. Jacka Woronieckiego, wielkiego wychowawcy polskiej inteligencji, jest znakomitą okazją do wzbudzenia refleksji nad tym, że człowiek dnia dzisiejszego zagubił się w rozróżnianiu tego, co warto kochać i podziwiać, a wobec czego można i nawet powinno się zdystansować.

Metodą analityczno-syntetyczną dokonano wyboru i interpretacji myśli dominikanina, będących przesłanką działania wychowawczego. Myśl pierwsza: „Znamiennym rysem postępowania ludzkiego [...] jest jego świadoma celowość”. Myśl druga: ,[...] w każdym [...] naszym uczynku kilka władz bierze udział, wypełniając w nim każda właściwą sobie rolę”. Myśl trzecia: ,[...] tylko ta etyka jest dobra i prawdziwa, która [...] uczy nie tylko o czynach dobrych i złych, ale też o stałych do nich usposobieniach, cnotach i wadach”. Myśl czwarta: „Każdy ma sobie wyznaczoną miarę doskonałości”. W koncepcji o. Jacka Woronieckiego wskazany jest znaczący potencjał człowieka. Z kolei współczesność wykazuje wielką podatność na zmiany. We wnioskowaniu więc zaproponowano połączenie tych dwóch przesłanek, wskazując na czas słusznej zmiany w kierunku godziwej etyki i godziwego życia.

Słowa kluczowe: Jacek Woroniecki; wychowanie; etyka; katolicka etyka wychowawcza.

\section{HUMAN UPBRINGING \\ IN THE PERSPECTIVE OF FATHER JACEK WORONIECKI EDUCATIONAL ETHICS}

The purpose of this article is to present the modern usefulness of father Jacek Woroniecki catholic educational ethics. The modern human, entangled in obtaining and gathering the material goods, as well as psychical and social ones, loses what is continuous and stable and collects what is transitory with its continuous change. The human loses the foundation for solid construction for instability and uncertainty. The 70th anniversary of father Jacek Woroniecki farewell, the great educator of Polish intelligence, is a perfect occasion to rise the reflections upon modern human that lost the ability to distinguish what is worth worshipping and admiring and what could be or even should be pushed away.

With the use of the analytic-synthetic method a choice and interpretation were made of the Dominican notion, which constitute a prerequisite to upbringing actions. The first thought: "The significant trait of the human actions [...] is the conscious purposefulness." The second thought: 
"[...] in our every action [...] a few forces participate, fulfilling appropriate role." The third thought: "[...] only this ethics is good and true, which [...] teaches not only about the good and bad actions but also about the continuous predispositions, virtues and faults." The fourth thought: "Everybody has appointed dose of excellence." In the father's Jacek Woroniecki concept, there is the depicted human's potential. On the other hand, the contemporaneity presents great susceptibility for change. Therefore, it has been proposed in the application to join these two phenomena, presenting to the time of the good change in decent ethics and decent life.

Key words: Jacek Woroniecki; upbringing; ethics; catholic educational ethics.

Translated by Irena Kalisz 